\title{
ESPAÇO TEMÁTICO: ESTADO, AUTORITARISMO E LUTA DE CLASSES
}

\section{Revolução burguesa dependente e contrarrevolução no Brasil}

\author{
Diogo Prado Evangelista ${ }^{1}$ \\ https://orcid.org/0000-0001-9876-7354 \\ ${ }^{1}$ Universidade Federal dos Vales do Jequitinhonha e Mucuri, Faculdade de Ciência Sociais Aplicadas e Exatas, \\ Departamento de Ciências Humanas e Sociais, Teófilo Otoni, MG, Brasil
}

\section{Revolução burguesa dependente e contrarrevolução no Brasil}

Resumo: Neste artigo pretende-se expor o resultado da pesquisa acerca do processo de revolução burguesa no Brasil e sua consolidação a partir do golpe empresarial-militar de 1964. Dessa maneira, revolução e contrarrevolução tornam-se estrutural para as transformações capitalistas e as formas ideológicas e políticas de dominação burguesa no País. Esses aspectos contribuem para elucidar a particularidade da forma política de democracia burguesa, desmistificando os elementos construtivos de sua ampliação e aprofundamento jurídico-legal como meio de emancipação política da população trabalhadora.

Palavras-chave: Revolução. Contrarrevolução. Autocracia Burguesa. Democracia de Cooptação.

\section{Dependent bourgeois revolution and counter-revolution in Brazil}

Abstract: In this article we intend to expose the result of the research about the process of bourgeois revolution in Brazil and its consolidation from the 1964 business-military coup. In this way, revolution and counter-revolution become structural for capitalist transformations and ideological and policies of bourgeois domination in the country. These aspects contribute to elucidate the particularity of the political form of bourgeois democracy, demystifying the constructive elements of its expansion and legal-deepening as a means of political emancipation of the working population.

Keywords: Revolution. Counterrevolution. Bourgeois Autocracy. Cooptation Democracy.

Recebido em 30.06.2020. Aprovado em 27.07.2020. Revisado em 28.08.2020.

(c) (\$) Este é um artigo publicado em acesso aberto (Open Access) sob a licença Creative Commons Attribution NonBY NC Commercial, que permite uso, distribuição e reprodução em qualquer meio, sem restrições desde que sem fins comerciais e que o trabalho original seja corretamente citado. 


\section{Introdução}

O tema da revolução e contrarrevolução burguesa no Brasil se apresenta sob dois movimentos socioeconômicos e culturais que coincidem historicamente nas décadas de 1960 e 1970. De um lado, a contrarrevolução preventiva e prolongada no interior dos países centrais do capitalismo monopolista; por outro lado, a particularidade dos mecanismos de revolução e contrarrevolução burguesa no Brasil.

A contrarrevolução burguesa nos países centrais do capitalismo se coloca como resultado de três fatores históricos articulados entre si: a) a dualidade de forças políticas, militares e econômicas da guerra fria entre os dois blocos societários; b) a aceleração desta correlação de forças com as crises econômicas nos países imperialistas, a partir de meados de 1960; e c) o colapso da aliança entre as classes sociais pela socialdemocracia no pós-Segunda Guerra Mundial.

A contrarrevolução se apresenta no interior dos países imperialistas como movimento de manipulação ideológica, desde as esferas da circulação de mercadorias e seu consumo até os desdobramentos profundos na cultura e na democracia burguesa do Estado de direito. Manipulação ideológica e irracionalismo imperialista resumem o movimento destrutivo e violento tanto no interior dos países imperialistas como nas válvulas de escape de sua crise econômica, política e social, realizadas a partir de interferências diretas sobre os países periféricos do capital, dentre estes, os países da América Latina. Dentro deste último aspecto que se inserem os mecanismos de revolução e contrarrevolução burguesa no Brasil.

Compreende-se que a revolução e contrarrevolução burguesa no Brasil encontram suas raízes na forma particular de objetivação do capital (passado colonial) e se realimenta desde o princípio da formação do Estado nacional brasileiro. Em outras palavras, desde as formas embrionárias da revolução burguesa no Brasil se desenvolveu, simultaneamente, processos de contrarrevolução burguesa que reitera, de maneira estrutural, as formas de violência política, cultural e econômica do "ordenamento senhorial-escravocrata" e do "modo de produção escravista-colonial” (FERNANDES, 2010, p. 29).

Para esclarecer essa conexão embrionária e estrutural da revolução e contrarrevolução burguesa no Brasil, assim como, a peculiaridade de sua sincronização com os processos imperialistas de contrarrevolução preventiva e prolongada nas décadas de 1960 e 70; torna-se necessário apresentar a concepção teórica de revolução burguesa no Brasil.

\section{A concepção teórica de revolução burguesa no Brasil}

Geralmente a concepção de revolução burguesa está associada a processos de insurreição social, derrubada do poder político dentro e fora do Estado moderno e com transformações sociais e econômicas, que romperam com os modos de produção anteriores/distintos e com as formas de sociabilidade correspondentes. Isto tem como referência as revoluções políticas clássicas da Inglaterra de 1640, a revolução francesa de 1789 e as revoluções econômicas do mercado mundial e da grande indústria, principalmente, a revolução industrial inglesa de 1780 a 1830. Isto não surpreende e na realidade se justifica, conforme estes exemplos clássicos de revolução burguesa. Porém, muitas vezes, revolução tornou-se sinônimo de insurreição, no caso da revolução burguesa, a luta de classes aparentemente se colocava entre burguesia versus monarquias nacionais absolutistas, alto clero etc. Alguns autores têm revelado a simplificação dessa imagem acerca da revolução burguesa, inclusive, da própria revolução francesa de 1789 (HOBSBAWM, 1996). Em consonância com essas elaborações que pretendem distinguir revolução de insurreição, importa destacar, neste momento, a seguinte concepção de Florestan Fernandes (1976, p. 203, grifo nosso):

Na acepção em que tomamos o conceito, Revolução Burguesa denota um conjunto de transformações econômicas, tecnológicas, sociais, psicoculturais e políticas que só se realizam quando o desenvolvimento capitalista atinge o clímax de sua evolução industrial. Há, porém, um ponto de partida e um ponto de chegada, e é extremamente difícil localizar-se o momento em que essa revolução alcança um patamar histórico irreversível, de plena maturidade e, ao mesmo tempo, de consolidação do poder burguês e da dominação burguesa. [....]. 
Nessa perspectiva, a revolução burguesa corresponde ao processo histórico de transformações societárias que encontra "[...] um patamar histórico irreversível [...]" a partir destes três aspectos: a) o "[...] clímax [...]" da "[...] evolução industrial [...]" capitalista; b) a consolidação do poder burguês"; e c) da "dominação burguesa" (FERNANDES, 1976, p. 203). Nos dois primeiros aspectos, as "transformações econômicas, psicoculturais e sociais" estão vinculadas à dinâmica e classificação social de indivíduos, grupos e classes sociais a partir do mercado, das relações sociais monetárias e da grande indústria. Esclarecendo, o poder burguês se refere ao processo de subsunção das formas de dominação anteriores pelas relações sociais monetárias que somente se expande e se consolida a partir da generalização do trabalho assalariado. Mas, também, a revolução burguesa se refere à dominação burguesa, ou seja, à polarização política da classe burguesa como classe dominante. Nesse último aspecto, cabe compreender o processo de formação de classe burguesa e sua crescente autonomia na condição de classe dominante. Em suma, a revolução burguesa corresponde ao resultado histórico da formação da sociedade burguesa como algo irreversível: não há retorno para trás.

No caso latino-americano, a sociedade burguesa encontra os seus embriões de desenvolvimento nas mudanças e transformações econômicas impostas pelos países centrais do capitalismo no século XIX, e na formação social das colônias de exploração das metrópoles espanholas e portuguesas. Embora, as colônias latino-americanas encontrem determinações comuns nessa pilhagem e formas sistemáticas de violência do sistema colonial; há peculiaridades, distinções históricas nessa formação social em cada região colonial, principalmente, nos aspectos de dominação-exploração das metrópoles vinculadas à escravidão de povos africanos e dos povos originários dessa região. Não cabe neste artigo a exposição dessas particularidades, porém, é importante observar a relevância dessa particularidade do Brasil Colônia como particularidade da particularidade latino-americana.

A formação da sociedade burguesa no Brasil tem como ponto de partida os mecanismos de supressão e desagregação com as formas sociais e econômicas edificadas no passado colonial, isto é, este processo está diretamente relacionado com o "problema da descolonização" (FERNANDES, 2015, p. 101).

Em termos gerais, o Brasil Colônia está articulado com o processo de acumulação primitiva do capital da Europa ocidental, seja no interior do sistema colonial, seja nas condições objetivas de gênese e desdobramento do sistema monetário internacional (ouro e prata) e do mercado mundial (comércio internacional). Porém, na condição de colônia de exploração da metrópole portuguesa, a base produtiva do capital se realiza a partir da exploração da força de trabalho escrava e apropriação privada da terra. Esta centralidade da exploração e dominação a partir do escravo e da terra torna-se substancial para a formação social específica, neste caso, o ordenamento social que gravita em torno da relação senhor-escravo. Portanto, o problema da descolonização se coloca na ruptura concreta com estes três aspectos: 1) a dependência econômica e política com as metrópoles; 2) o modo de produção escravista-colonial; 3) o ordenamento senhorial-escravocrata (FERNANDES, 2010, p. 43).

A partir da segunda metade do século XVIII, conflitos e tensões sociais tornaram-se crescentes pelas interferências externas e as mudanças internas, nesse movimento contínuo de fora para dentro. Dentre as interferências externas destacam-se: a descoberta do ouro; a plantação de algodão; a revolução francesa de 1789 (PRADO JÚNIOR, 2012). Essas interferências correspondiam a mudanças internas no Brasil Colônia que colocaram em movimento processos de desagregação social e econômica que mantinha o ordenamento senhorial-escravocrata, principalmente, os privilégios políticos, sociais e culturais, assim como as vantagens econômicas dos estamentos senhoriais. Essa dinâmica de mudanças oriundas de fora para dentro, tornaram-se explícitas nas exigências e necessidades inglesas, seja na transposição do setor urbano-comercial para dentro da ex-colônia, seja na abolição da escravatura no século XIX. O que fica evidente com esses fatos históricos de interferências externas da metrópole portuguesa e, indiretamente da Inglaterra etc.?

Primeiro, a dinâmica de mudanças sociais e econômicas é determinada pelo movimento e interesse do capitalismo de fora para dentro. Segundo, os comportamentos, reações dos estamentos senhoriais dominantes, desde o Brasil Colônia, corresponde a uma adaptação que procura delimitar o ritmo histórico dessas mudanças ao movimento "gradual, lento e seguro", que concilia socialmente as formas decadentes e em desagregação do domínio estamental-senhorial com as novas exigências da sociedade burguesa em formação (FERNANDES, 2010). No primeiro aspecto, se evidencia uma contínua interferência de fora para dentro que coloca mudanças e transformações que desagregaram as formas de dominação e exploração das elites brasileiras, e, por isso, colocaram em risco contínuo as formas de se manter no topo do poder político e econômico. Mas, cabe 
perguntar: por que não há ruptura com essas interferências externas? Por que não há uma luta desses estamentos senhoriais, dessa elite dominante contra a dependência servil aos países estrangeiros? Alguns responderiam: não há força social e econômica suficiente para esta ruptura. E, por que não há esta força social e econômica? Poder-se-ia justificar pela formação de uma mentalidade servil em termos políticos e culturais das elites brasileiras. Porém, estas últimas foram forjadas sobre a base da exploração-dominação do trabalho escravo. Aqui encontra-se o centro da questão.

O grau histórico de exploração da força de trabalho dos produtores, dos povos indígenas e africanos, na condição de escravo e todas as formas sistemáticas de torturas para essa acumulação de capital; assim como, as cristalizações sociais provindas das justificativas ideológicas de superioridade de raça e gênero, do homem branco, que foram cimentadas pela cooptação religiosa da igreja católica sobre a cultura desses povos; determinaram em seu conjunto este "prestígio social" dos estamentos-senhoriais que se evidenciaram nas reações, comportamentos e mentalidade política e cultural. O escravo é colocado como o inimigo público da sociedade escravista-colonial (FERNANDES, 2010).

Dessa maneira, a ruptura da elite brasileira com a dependência externa exigiria a mobilização política e social dessa massa de escravos e de setores médios, secundários do ordenamento senhorial-escravocrata. Porém, a elite brasileira receava perder o controle dos acontecimentos, assim como, o seu lugar privilegiado e monopolizado no centro de decisões internas do país ${ }^{1}$. Ademais, a emergência do setor urbano-comercial e a abolição da escravatura nessa nova dependência neocolonial com a Inglaterra, teve que se desenvolver a partir da acumulação primitiva de capital, baseada na exploração dessa força de trabalho escrava. Emerge dessa situação uma dupla articulação estratégica para a acumulação de capital, como algo necessário para realizar as transformações capitalistas, a formação do Estado nacional e o aburguesamento da elite brasileira, ou seja, a formação da classe burguesa e sua consolidação como classe dominante no Brasil. Qual seria essa dupla articulação estratégica no período de 1822 a 1889 ?

Em primeiro lugar, a articulação entre os interesses da elite brasileira, a economia brasileira, na condição de sócia menor com os interesses e demandas do mercado mundial e os seus países hegemônicos.

Em segundo lugar, a articulação entre a estrutura agrária e a continuidade da escravidão com a revolução urbano-comercial. Dessa segunda articulação, a elite brasileira garante o seu monopólio no centro de decisões internas do Estado nacional. Esse processo político estava vinculado às transformações econômicas da esfera urbano-comercial que se balizou tanto na acumulação primitiva de capital no setor agroexportador como no circuito fechado do próprio mercado interno dessas relações sociais monetárias (FERNANDES, 1976). Nesse sentido, a segregação social e o patriarcado tornaram-se sistemáticos e estruturais para o desenvolvimento do capitalismo no Brasil.

Em resumo, a permanência do desenvolvimento desigual interno tornou-se vantajoso para elite brasileira se adaptar às transformações capitalistas de fora para dentro. No interior desse processo de desagregação social tornou-se estratégico para se formar e polarizar como classe burguesa dominante criar os seguintes mecanismos do circuito fechado: a) econômicos, sob a base de superexploração da força de trabalho e a elitização do mercado interno; b) políticos, na especialização brasileira de democracia restrita; c) cultural, racismo e patriarcado. O circuito fechado do monopólio do poder econômico e político da burguesia no Brasil entra em contradição frontal com o próprio desenvolvimento capitalista, precisamente, a questão do regime de classes sociais e a integração política do Estado. Por isso, a polarização política da classe burguesa se efetivou a partir da inibição frontal (violenta) e indireta as potencialidades de polarização da classe trabalhadora como classe em si. Nesse sentido, o Estado nacional se coloca como barreira para as possibilidades e potências da formação da Nação brasileira, assim como a sociedade burguesa no Brasil se desenvolve no congelamento da descolonização que se traduz na modalidade de capitalismo dependente e do subdesenvolvimento social.

\section{Por que a revolução burguesa se consolida no golpe empresarial-militar de 1964 no Brasil?}

Nas décadas de 1970 e 1980, uma diversidade de autores brasileiros procuraram realizar um balanço crítico sobre as causas e fatores que levaram ao golpe empresarial-militar de 1964 e seu significado histórico-social. De acordo com Caio Prado Jr. (1977) alguns dos equívocos da esquerda brasileira consistia numa estratégia política que tinha como pressuposto a existência de um conflito intraclasse burguesa com duas direções ou 
interesses para os rumos do País. Esse pressuposto identificou, erroneamente, alguns setores da burguesia que pudessem ter força e direção anti-imperialista e que poderiam levar a cabo, com o apoio da esquerda brasileira e da classe trabalhadora, as reformas estruturais no Brasil. Numa outra perspectiva de análise, Ruy Mauro Marini (2013) demonstra neste contexto histórico nas décadas de 1950 e 1960, a crescente associação da economia e do Estado brasileiro aos mecanismos e dinâmicas do imperialismo estadunidense. Esse aspecto se explicava pelo grau de desenvolvimento capitalista no País e as relações econômicas e políticas com outros países da América Latina. Nessa perspectiva, a burguesia brasileira estaria associada ao imperialismo estadunidense, porém, teria força social e econômica o suficiente para se impor interna e externamente, isto é, como país que representasse o imperialismo na região. Inclusive como suporte das forças armadas contrarrevolucionárias contra os movimentos nacionalistas e anti-imperialistas.

De acordo com Florestan Fernandes (1976), a contrarrevolução preventiva do golpe empresarial-militar significou a concretização da revolução burguesa dependente no Brasil. Os conflitos, pressões internas e externas que se apresentaram nesse contexto histórico foram expressões das contradições internas do capitalismo competitivo dependente no Brasil. Com a ampliação e aprofundamento da ordem social competitiva e da grande indústria correspondente, emerge como resultado histórico a diferenciação crescente do regime de classes que encontrou barreiras na restauração da democracia restrita no pós-Estado novo.

Essa diferenciação do regime de classes significou o aumento dos setores médios da sociedade brasileira, tais como os profissionais liberais, a imprensa brasileira, servidores públicos etc.; que se organizaram, necessariamente, em partidos, sindicatos e associações. Ademais, o avanço paulatino do trabalho assalariado das grandes metrópoles para o campo, assim como a proletarização crescente dos trabalhadores assalariados vinculados diretamente com o desenvolvimento industrial brasileiro; apresentam a tendência crescente de polarização da classe trabalhadora como classe em si. Importante observar que esse último aspecto entra em contradição com as formas híbridas de exploração da força de trabalho (escravidão, semilivre e servidão), colocando, aos poucos a questão da classificação social dos indivíduos pelo mercado e os mecanismos de integração política do Estado de direito. Desses setores heterogêneos da população trabalhadora do Brasil, em suas diversas facetas, tais como a Liga Camponesa, o movimento estudantil, os sindicatos e os partidos do PCB (censurado e proibido) e PTB; pode-se compreender a elaboração do conjunto de pautas das "Reformas de Base", sendo destacados os seguintes pontos: reformas estruturais para a ampliação da democracia formal burguesa (sufrágio universal) e autonomia econômica nacional, isto é, as reformas burguesas da democracia e da soberania nacional, traduzidas na reforma agrária, urbana, educacional, tributária e sistema político. No entanto, esses setores médios e as organizações da população trabalhadora se localizavam em espaços políticos isolados e fragmentados da sociedade brasileira ${ }^{2}$. Em outros termos, esse conjunto de forças sociais exerciam pressões internas insuficientes para se polarizar como classe social autônoma em nível nacional diante da alta classe burguesa e da classe média dominantes no Brasil.

Por outro lado, essas pressões foram nutridas e aproveitadas por segmentos da classe burguesa no Brasil que se encontravam no conflito intraclasse social para disputar as vias de desenvolvimento do capitalismo. Esses segmentos foram representados, de maneira demagógica e ilusória, por exemplo, na campanha O petróleo é nosso! Esses segmentos da classe burguesa têm como determinações objetivas de classe as novas esferas econômicas que surgiram e se desenvolveram desde os anos de 1930, no Brasil. Tem-se como referência as condições econômicas do capitalismo dependente que propiciaram, pela via do Estado moderno, a edificação de indústrias que estavam associadas, de maneira segmentária, às grandes corporações e seus governos hegemônicos, ou seja, as chamadas empresas estatais não passavam de indústrias mistas de associação e propriedade entre o Estado nacional e os países imperialistas, principalmente, voltadas para a energia, meios de comunicação e transporte no Brasil. Por outro lado, emerge e se desenvolve, desde fins da Primeira Guerra Mundial, a indústria de substituição de importações.

Nessa segunda via de pressões internas no País, o conflito intraclasse burguesa desencadeou uma instabilidade política e social. Porém, esses conflitos e pressões internas intraclasse burguesa não eram o suficiente para gerar uma crise do poder burguês no Brasil. E por que eram insuficientes? O golpe empresarialmilitar no Brasil responde essa questão. Os segmentos da classe burguesa que se intitulavam como nacionalistas pretendiam levar o desenvolvimento econômico do capitalismo no Brasil, a partir de ritmos históricos controlados pelo Estado brasileiro; no entanto, estava fora do programa político as reformas estruturais, que de fato colocasse neste plano político e econômico o enfrentamento dos mecanismos sistemáticos de segregação 
social (subdesenvolvimento) e o problema da descolonização (capitalismo dependente). Esclarecendo, esses segmentos da elite brasileira não procuravam mobilizar a sociedade brasileira para a ruptura com a dependência servil da economia ao mercado mundial. Posto que a mobilização colocaria nas pautas de luta social, por exemplo, a necessidade de realizar a reforma agrária e estabelecer um novo padrão de desenvolvimento social, econômico e político para a população trabalhadora no Brasil. Os limites desse conflito intraclasse burguesa ficou evidente, na medida em que se acelerava o golpe empresarial-militar, nos anos de 1963-64 e com o isolamento político de João Goulart.

Nessa perspectiva de análise, a instabilidade política e social somente tornou-se numa crise do poder burguês quando as pressões externas das corporações multinacionais colocaram a necessidade de estabelecer uma nova modalidade de dependência econômica e política do Brasil ao imperialismo estadunidense. No interior do País, essa nova modalidade de dependência econômica encontrou apoio de algumas instituições, empresas e setores sociais vinculados às primeiras manifestações de irrupção do capitalismo monopolista, que teve início desde fins da Primeira Guerra Mundial. Isso se explica pelas três vias de acumulação capitalista no Brasil: 1) agroexportação e mineração; 2) indústria de substituição de importações; e 3) empresas mistas de energia, comunicação e transporte. Importante observar a apropriação e deslocamento do ciclo de acumulação de capital da esfera agrária para o surgimento das indústrias de substituição de importações, isto é, os fazendeiros de café foram os primeiros capitães industriais do Brasil, o que refuta a existência de um conflito entre os ruralistas e industrialistas. Outro ponto de destaque está na associação do processo de nacionalização e estatização de indústrias, que desde a sua origem está comprometida com os investimentos financeiros e tecnológicos dos países imperialistas. De maneira segmentada o capitalismo monopolista, as grandes corporações, já se encontravam no País. No entanto, a segunda irrupção do capitalismo monopolista na década de 1950 antecipou a questão objetiva sobre as novas modalidades de dependência ao capitalismo monopolista e de subdesenvolvimento no País.

É na década de 50 que se pode localizar a segunda tendência de irrupção do capitalismo monopolista como realidade histórica propriamente irreversível. Nessa fase, a economia brasileira já não concorre, apenas, para intensificar o crescimento do capitalismo monopolista no exterior: ela se incorpora a este crescimento, aparecendo, daí em diante, como um de seus polos dinâmicos na periferia. [...] implantar dentro do País o esquema de organização e de crescimento econômicos intrínsecos à grande corporação. [...] (FERNANDES, 1976, p. 255-256).

Esta pressão externa significava mudanças e transformações capitalistas que colocavam em desagregação as formas de dominação e exploração das elites brasileiras e a diminuição de espaço no centro de decisões internas do país. Portanto, um dilema teórico se colocava para a elite brasileira: romper com o imperialismo e garantir a continuidade de seu espaço nas decisões internas no país ou se adaptar as transformações capitalistas e garantir a permanência, embora diminuta, no topo do poder político e econômico do Brasil. Esse dilema é meramente teórico porque não expressava objetivamente a formação da classe burguesa, do poder burguês e da dominação burguesa no Brasil. Dessa maneira, a via de adaptação às transformações capitalistas do imperialismo (de fora para dentro) e a ditadura de classes (dominação burguesa interna) colocou a contrarrevolução preventiva na via de concretização da revolução burguesa dependente no Brasil. Poder-se-ia perguntar: mas teria como barrar a inserção do padrão de capitalismo monopolista na estrutura social brasileira?

A "decisão interna" de permitir e, mais do que isso, de facilitar e de acelerar a irrupção do capitalismo monopolista, como uma transição estrutural e histórica, não possui o mesmo peso econômico que os dois fatores anteriores. No entanto, ela é central. Na sua ausência, as grandes corporações não contariam como espaço econômico e político para ir tão longe. O que quer dizer que continuariam indefinidamente presas à operação de controles econômicos segmentares, intrínsecos à sua participação na vida econômica do País (o que não as impediria de retirar o melhor quinhão do crescimento econômico interno). (FERNANDES, 1976, p. 257-258).

Como estava interditada qualquer possibilidade de escolha pela burguesia brasileira de realizar a revolução nacional e democrática no Brasil, conforme foi apresentado até aqui, a alta burguesia decide em favor desse impulso externo por duas razões. Primeiro, para enfrentar a partir da ditadura de classe tanto as 
pressões internas dos setores médios e da população trabalhadora organizada no Brasil quanto a instabilidade econômica e social do conflito intraclasse burguesa. Era necessário acabar com as ilusões demagógicas do jogo político eleitoral. Segundo, permanecer no centro de decisões e participar na apropriação privada do mais-valor capitalizado a partir desse novo padrão de acumulação capitalista.

[...] Se tudo ficasse, pura e simplesmente, ao arbítrio das grandes corporações e dos interesses econômicos ou políticos das nações hegemônicas, burguesia e Estado nacional perderiam, ao mesmo tempo, os anéis e os dedos. Estariam trabalhando não por uma nova transição econômica dentro do capitalismo, passível pelo menos de controle político interno, porém, por uma reversão colonial ou neocolonial insofreável. (FERNANDES, 1975, p. 259).

A reversão neocolonial evitada naquele momento do golpe empresarial-militar de 1964, retorna nas décadas de 1980 e 1990 como resultado das transformações capitalistas correspondentes no período. Em outros termos, os novos "[...] requisitos estruturais e dinâmicos do padrão de desenvolvimento econômico inerente ao capitalismo monopolista [...]" resultou no desaparecimento da esfera "fora" e "dentro" da economia brasileira e transformou estruturalmente o nosso país. Porém, essa transformação não significou a liquidação da via colonial de capitalismo dependente.

[...] O capitalismo monopolista não eclode nas economias periféricas rompendo o seu próprio caminho, como uma força interna irreprimível que destrói estruturas econômicas arcaicas ou simplesmente obsoletas, dimensionando e reciclando o que deveria ser preservado e forjando suas próprias estruturas econômicas ou extra-econômicas. Vindo de fora, ele se superpõe, como o supermoderno ou o atual, ao que vinha de antes, ou seja, o "moderno", o "antigo" e o "arcaico", aos quais nem sempre pode destruir e, com frequência, precisa conservar. O seu maior impacto construtivo consistem em cavar um nicho para si próprio, naquelas esferas das economias periféricas que são mais compatíveis com a transição, formando assim um exíguo espaço econômico, a partir do qual poderá crescer e quiçá irradiar-se para toda a economia, universalizando aos poucos os requisitos estruturais, funcionais e históricos inerentes ao seu próprio padrão de desenvolvimento capitalista. (FERNANDES, 1976, p. 268-269).

Essas considerações de Florestan Fernandes contribuem para analisar o caminho das economias periféricas na articulação entre a reprodução de estruturas econômicas da via colonial com a universalização do padrão de capitalismo monopolista. Uma nova síntese histórica emerge a partir dessas transformações estruturais da sociedade brasileira na reposição sob novas bases o subdesenvolvimento no País.

\section{Quais foram as transformações capitalistas estruturais da revolução burguesa no Brasil?}

Para responder a essa questão, é importante destacar a nova modalidade de capitalismo dependente no Brasil e como essas transformações capitalistas delimitaram a peculiaridade da revolução burguesa dependente. Florestan Fernandes (1975, p. 18-19, grifo nosso) sintetizou essa nova modalidade no conceito de "imperialismo total" nos seguintes termos:

O traço específico do imperialismo total consiste no fato de que ele organiza a dominação externa a partir de dentro e em todos os níveis da ordem social, desde o controle da natalidade, a comunicação de massa e o consumo de massa, até a educação, a transplantação maciça de tecnologia ou de instituições sociais, a modernização da infra e da superestrutura, os expedientes financeiros ou do capital, o eixo vital da política nacional etc. Segundo esse tipo de imperialismo demonstra que mesmo os mais avançados países latino-americanos ressentem-se da falta dos requisitos básicos para o rápido crescimento econômico, cultural e social em bases autônomas. [...] Terceiro, ela prova que uma economia satélite ou dependente não possui as condições estruturais e dinâmicas para sobrepujar nacionalmente, pelos esforços de sua burguesia (isto é, lato sensu, os setores dominantes das classes alta e média), o subdesenvolvimento e suas consequências. [...].

A análise das transformações estruturais da sociedade brasileira sob o imperialismo total reside na articulação entre quatro aspectos: 1) as modificações do processo de acumulação de capital monopolista no 
Brasil; 2) o regime de classes; 3) a indústria cultural; e 4) a estrutura política da autocracia burguesa no interior do Estado moderno.

Cabe num artigo apresentação sumária do período conturbado e heterogêneo da ditatura de 1964 a 1985. O objetivo da pesquisa realizada foi demonstrar a permanência dos mecanismos de contrarrevolução por via das transformações capitalistas e suas incidências na vida social brasileira. Em outros termos, procura-se apresentar no resultado desta pesquisa alguns elementos que possam elucidar o conteúdo da contrarrevolução prolongada que permanece e adquire uma forma específica na democracia burguesa no Brasil.

A investigação científica do processo de inserção do imperialismo total no Brasil identificou no planejamento econômico da ditadura a espinha dorsal desse processo histórico de 1964 a 1985. Porém, acompanha-se com este planejamento mudanças substantivas na legislação trabalhista e no sistema previdenciário no Brasil.

O I Plano Nacional de Desenvolvimento (I PND), elaborado em 1970 se articula aos processos anteriores e sua aplicação. Destaque para o Plano de Ação Econômico do Governo (PAEG) de 1964 a 1967, que constituiu um conjunto de reformas tributárias, bancária e monetárias que resultaram na ampliação dos impostos indiretos (arrocho salarial), na criação do Banco Central e de uma política de crédito que favoreceu as grandes empresas (PAULO NETTO, 2014, p. 91). Outro aspecto de relevância foi a criação do Fundo de Garantia do Tempo de Serviço (FGTS) em 1966, que possibilitou a extinção da estabilidade do emprego e a dispensa dos trabalhadores. Embora, tenha sido opcional, o FGTS em sua prática foi colocado como obrigatório nos contratos de trabalho. Ainda nos termos da legislação trabalhista, a criação do Instituto Nacional de Previdência Social (INPS), em 1966. De um lado, o INPS abriu caminho para ampliação em nível nacional de sua aplicação e, por intermédio disto, na criação de novos postos públicos e demandas de técnicos-profissionais. Por outro lado, favoreceu a medicina privada e os planos privados de saúde. Esse conjunto de medidas econômicas, trabalhistas e previdenciárias corresponderam ao pacote de inserção do imperialismo total (PAULO NETTO, 2014).

Por último, a revogação da Lei de Remessa de Lucros de 1962 possibilitou a drenagem do maisvalor capitalizado para as grandes corporações e seus órgãos governamentais, assim como a entrada dessas corporações no País, com destaque para a Agência de Desenvolvimento Internacional dos Estados Unidos (USAID), gerenciada pela CIA. (PAULO NETTO, 2014).

No conjunto, essas medidas da política econômica e social da ditadura anteciparam as orientações da macroeconomia brasileira da década de 1970 e seus gargalos crônicos na década de 1980 .

O modelo econômico implantado na década de 1970 significou a refundação da economia brasileira no entrelaçamento orgânico e estrutural com as grandes corporações do capitalismo monopolista no interior do País. Observa-se, no período de 1970 a 1974, uma nova articulação entre Estado e capital estrangeiro, no que se refere às condições vantajosas para investimentos e ampliação das indústrias no Brasil sobre o domínio do monopólio do capital estrangeiro. Vale a pena ressaltar os seguintes setores: mecânica; material elétrico e de comunicações; material de transportes; farmacêutica e alimentícia. Embora, a presença de estatais nas indústrias de extração mineral, siderúrgicas e química pudessem se apresentar como exceção, na realidade expressam o monopólio das estatais e do capital estrangeiro.

Nos anos de 1964 a 1970, a reforma bancária e monetária foram molas propulsoras para a centralização de capitais, no que se refere à facilidade de créditos para empresas de grande porte e a revogação da Lei de Remessas de Lucros privilegiaram investimentos e inserção do capital estrangeiro no País. Este processo preparou a monopolização de acumulação de capital estrangeira no País, cujo resultado se apresenta nesse modelo econômico.

A industrialização capitalista da agricultura no Brasil se apresentou como outro tentáculo do capital monopolista e o equivalente da revolução agrícola burguesa, porém, sob o domínio e articulação do imperialismo. Dados estatísticos do censo de 1972, referentes à "[...] área superior a dez mil hectares [...]" demonstram que "[...] 33\% pertenciam a pessoas jurídicas estrangeiras (situados especialmente no Mato Grosso, Pará, Amapá e Roraima) [...]". O que revela a apropriação do capital monopolista sobre a propriedade de terra, assim como os novos impulsos modernizadores nas atividades agrícolas; na utilização de tecnologias, instrumentos e métodos vinculados à segunda revolução industrial. Essa "modernização" se efetivou na agricultura e pecuária brasileira com os estímulos da Empresa Brasileira de Pesquisa Agropecuária (EMBRAPA) de 1972 a 1973. Dessa maneira, a industrialização capitalista no campo resultou numa nova concentração crescente de propriedades por uma minoria e uma expropriação violenta dos trabalhadores rurais do campo que se tornaram temporários. Nessa esfera da indústria brasileira (agricultura e pecuária) se reproduziu a via colonial de produção destinada 
e determinada pelo mercado mundial. O que significa ignorar a necessária revolução agrícola voltada para o mercado interno e as necessidades nacionais. E, esse aspecto explícito na agricultura da transformação da sociedade brasileira numa Nação do capital, que inviabiliza estruturalmente qualquer possibilidade de uma integração nacional interna, corresponde, em seu todo, ao modelo econômico que resultou na crise em meados de 1970 e em toda a década de 1980.

Em termos gerais, o modelo econômico não rompeu com a elitização e monopólio do mercado interno do País, sistematicamente efetivado para manter o desenvolvimento desigual interno. De acordo com Paulo Netto (2014, p. 147), 15-20\% da população brasileira acessavam os produtos do mercado interno no país na década de 1960. Essa contradição entre o desenvolvimento e expansão da capacidade de produção industrial, principalmente, dos bens de consumo duráveis e o mercado interno seletivo estava balizada pelo arrocho salarial, concentração de renda e propriedade privada. Uma política econômica voltada internamente para os "[...] 15\% da camada média [...]" e "[...] os $5 \%$ dos mais ricos [...]" e, externamente, pela entrega de propriedades de terra, recursos naturais e investimentos industriais ao capital estrangeiro (PAULO NETTO, 2014, p. 156).

O desenvolvimento industrial brasileiro estava, desde o início, articulado com as políticas públicas e sociais do Estado, assim como na produção dos consumidores, nos termos de Marx (2011). As indústrias de bens de consumo duráveis foram a base produtiva para as transformações profundas dos meios de transporte (rodovias), meios de comunicação (televisão) e energia (siderurgia, petróleo e eletricidade). Essas transformações se revelam pelo consumo de automóveis, televisão, eletrodomésticos etc.; que equalizam os indivíduos, grupos sociais e classes sociais a uma identidade cultural com o estilo de vida norte-americano; seja nos indivíduos e grupos sociais que acessam essas mercadorias; seja a população que aspira adquirir esse lugar na sociedade.

Dessa maneira, indicamos, sumariamente, a articulação da industrialização brasileira com a inserção e aprofundamento da indústria cultural e suas incidências na nova fisionomia dos setores médios e da classe burguesa no Brasil. Os setores médios já se encontravam, em suas aspirações sociais, num divórcio com os trabalhadores assalariados, porém, a indústria cultural realiza esta conexão entre os setores médios dominantes com os interesses e necessidades do grande capital.

Nos anos de 1960 a 1970, o modelo econômico propiciou, também, mudanças significativas na formação da classe burguesa no Brasil, no sentido de diluir os elementos que davam sustentação para o conflito intraclasse burguesa anterior ao golpe de 1964. A nova modalidade de dependência econômica se traduz, também, no novo padrão cultura da burguesia brasileira. O ethos burguês anterior articulava o cosmos patrimonialista herdado pelo passado colonial com o empresário moderno da ordem social competitiva. Porém, com o imperialismo total, a racionalidade burguesa significa uma identidade imediata entre o seu comportamento, mentalidade, enfim, os traços psicossociais com os interesses, necessidades do imperialismo estadunidense. Nos termos de Florestan Fernandes (1976, p. 312),

[...] Essa reviravolta ideológica e utópica quanto às suas repercussões no plano interno, não só aumenta o grau de alienação filosófica, histórica da burguesia perante os problemas nacionais e sua solução. Ela fortalece a insensibilidade diante deles, na medida em que não perturbem o desenvolvimento capitalista interno nem o "equilíbrio do sistema capitalista mundial", ou ainda, na medida em que sejam úteis para a intensificação da acumulação capitalista. [...].

Nesse sentido, a burguesia brasileira adquire um aspecto cosmopolita que compreende e age diante dos problemas nacionais a partir dos interesses pró-imperialistas. Na realidade, a esfera dentro e fora do país, assim como, capital nacional e capital estrangeiro tornam-se obsoletos. Porém, os problemas nacionais não desapareceram, assim como, as contradições internas do capitalismo dependente que repercute no regime de classes não foram superadas; permanece na história brasileira a dependência, porém, nesse momento, nas entranhas da vida econômica e social brasileira, com a dinâmica das forças sociais, políticas e econômicas do capital monopolista. O desenvolvimento desse novo padrão de acumulação monopolista de capital no país não suprime as bases constitutivas do subdesenvolvimento, o que revela o retorno crônico e trágico dos antagonismos de classes. 


\section{A autocracia burguesa entrou em colapso no processo de abertura democrática no Brasil?}

A industrialização brasileira traz consigo a proletarização crescente da população trabalhadora no Brasil e aprofunda a diferenciação do regime de classes que entra em antagonismo com o circuito fechado do Estado e do mercado, traduzido pela ditadura do capital e da elitização da esfera do consumo de mercadorias. Essas pressões, divergências e conflitos de classes se apresentaram em todo esse período histórico; às vezes frontalmente, nos anos de 1967-1969, cujo resultado foi o recrudescimento da violência da ditadura de classes com o AI-5; um tanto decrescente nos anos de 1970-1973, pela mistificação do modelo econômico que ficou conhecido como Milagre; e o retorno dessas pressões internas, a partir de 1977 com a publicização do falseamento de dados, o arrocho salarial escancarado e a crise econômica no País. Importante ressaltar, a forma inédita da inserção do movimento operário na cena política nesse período final. Esses aspectos do modelo macroeconômico em conjunto com as novas fisionomias das classes dominantes, os setores médios e o ressurgimento das pressões internas do regime de classes explicam a formação da estrutura política da autocracia burguesa.

No período de 1964-1969, a ditadura empresarial-militar teve que enfrentar as dissidências e, ao mesmo tempo, consolidar a solidariedade de classes burguesa na concentração e centralização do poder real de dominação burguesa, a partir da violência direta do Estado nacional sob duas vias simultâneas. Primeiro, pelos atos institucionais e de legislações específicas no setor trabalhista, previdenciário e tributário. Segundo, pela reestruturação da segurança nacional (militarização da polícia civil) e órgãos de tortura e extermínio. No conjunto, essas duas vias revelam abertamente a ditadura de classe burguesa no País, que torna o poder político do Estado nacional numa identidade com poder burguês da classe burguesa. De acordo com Florestan Fernandes, esse domínio autocrático da burguesia em nível nacional, por intermédio do poder político do Estado, tornou-se o equivalente à revolução nacional, porém, pró-imperialista.

Nos anos 70, os elementos da contrarrevolução preventiva se camuflam num sincretismo que abriu espaço político para uma diminuta e artificial representação democrática e pluralista para os cidadãos válidos; mas, ao mesmo tempo, a reprodução dos aspectos paternalistas-tradicionais com o autoritarismo moderno. Este último é a institucionalização da violência e do terror fascistas que se estabelece tanto nos mecanismos de segurança nacional quanto na base legal-jurídica do Estado. Nos termos de Florestan Fernandes (1976, p. 350), a autocracia burguesa é a unidade entre "opressão para a maioria" e "democracia, liberdade para a minoria dominante".

A estrutura política da autocracia burguesa modifica, lentamente, a sua forma política de dominação a partir de 1975, no governo de Geisel, no processo de institucionalização e busca pela sucessão da corporação militar na transição democrática. Num primeiro momento, a autocracia burguesa ensaia a transição democrática na abertura de espaço político para os setores médios dominantes.

[...] A cooptação se dá entre grupos e facções de grupos, entre estratos e facções de estratos, entre classes e facções de classes, sempre implicando a mesma coisa: a corrupção intrínseca e inevitável do sistema do poder resultante. Além disso, a cooptação se converte no veículo pela qual a variedade de interesses e de valores em conflito volta a cena política, nela se instala e ganha suporte ou rejeição. Desse ângulo, a autocracia burguesa leva a uma democracia restrita típica, que se poderia designar como uma democracia de cooptação. [...] Graça a ele, os estratos médios ganham no rateio e se privilegiam muito acima de seu próprio prestígio social, movendo as alavancas do aparato estatal que estão nas mãos da burguesia burocrática, tecnocrática e militar. Ao mesmo tempo, também graças a ele, os "interesses verdadeiramente fortes" e os "interesses dominantes" deparam, enfim, com o seu meio político ideal, podendo impor-se à vontade, "de cima para baixo", e florescer sem restrições. [....] (FERNANDES, 1975, p. 358-359, grifo nosso).

A abertura de espaço político para os conflitos no interior da autocracia burguesa significa um processo de cooptação dos interesses e segmentos dos setores médios aos interesses da alta burguesia e do grande capital. Nesta estrutura política do Estado brasileiro, a corrupção não é, apenas, um desvio moral do caráter individual do político, do servidor público etc.; mas um sistema de poder que é intrínseco a cooptação para a permanência da autocracia burguesa. Desde o período do governo de Geisel até a transição de Figueiredo, assiste-se a abertura democrática no interior da ditadura. Porém, a abertura foi o ensaio de uma nova modalidade de democracia restrita correspondente ao novo padrão de acumulação capitalista desenvolvido no Brasil. Vale a pena lembrar que a democracia restrita é uma regra geral na história brasileira. Porém, ela se modifica na forma e conteúdo 
em cada época histórica, tais como, na velha república, na abertura democrática após o Estado Novo e na abertura da década de 1980. Antes de avançar para a peculiaridade que responde a questão colocada na última seção deste artigo, é importante destacar os aspectos centrais da democracia de cooptação: 1) um sistema de poder balizado pela corrupção; 2) integração política da variedade de interesses de valores em conflito do regime de classes pelo Estado; 3 ) vantagens econômicas e políticas dos setores médios dominantes no rateio do mais-valor capitalizado e valorizado no país; 4) a imagem e concepção de mundo dos setores médios ao prestígio social da alta burguesia, embora, não alcancem objetivamente esses privilégios; 5) a inserção dos setores médios na cena política enquanto alavancas do aparato estatal sob domínio e monopólio da burguesia burocrática, tecnocrática e militar; 6) o meio político de florescimento sem restrições dos interesses dominantes da burguesia pró-imperialista.

O desenvolvimento capitalista no Brasil desencadeou uma diferenciação do regime de classes que forjou a necessidade de ampliação da participação política no interior do Estado moderno. Essa tensão estrutural e histórica entre a diferenciação crescente do regime de classes e o circuito fechado da dominação burguesa foi, provisoriamente, liquidada no período da ditadura militar que, embora, sem planejamento prévio, conseguiu instituir no interior da autocracia burguesa uma nova modalidade de democracia restrita, a democracia de cooptação. A partir dos anos de 1977 e 1978, a abertura democrática para os setores médios se ampliam, paulatinamente para baixo.

\begin{abstract}
Pode-se concluir, pois, que está em curso uma dupla "abertura”. Ela não leva à democracia burguesa, mas à consolidação da autocracia burguesa: $1^{\circ}$ ) por pretender ampliar e consolidar a democracia de cooptação, abrindo-a "para baixo" e para a dissidência esterilizada ou esterilizável; $2^{\circ}$ ) por querer definir o alcance do poder legítimo excedente, que deve ser conferido constitucional e legalmente ao Estado autocrático. Não se trata de um retorno à democracia, que nunca existiu, nem de uma tentativa de abrir o caminho para uma "experiência democrática" autêntica. O que as classes burguesas procuram é algo muito diverso. Elas pretendem criar condições normais para o funcionamento e o crescimento pacíficos da ordem social convulsionada, que se achava estabelecida antes de 1964. E foi convulsionada em seus fundamentos ideais, e revitalizada, em seus fundamentos econômicos, sociais e políticos, pelo desenvolvimento econômico acelerado e pela contrarrevolução preventiva. Nem elas podem ou poderiam ir mais longe. [...] (FERNANDES, 1976, p. 363, grifo nosso).
\end{abstract}

Embora, a análise de Florestan Fernandes sobre as tendências acerca da abertura democrática tenha sido publicada em 1976, ou seja, antes da década de 1980, parece relevante destacar a ampliação e consolidação da democracia de cooptação como continuidade da autocracia burguesa. O que se apresenta como o término da contrarrevolução burguesa ditatorial, na realidade é a metamorfose desta última na forma política da democracia. Em alguns momentos a contrarrevolução sobre um refluxo pelas conquistas e avanços pontuais da classe trabalhadora, embora, nos mecanismos econômicos permanece no drama do subdesenvolvimento. $\mathrm{O}$ refluxo da contrarrevolução e sua base objetiva de existência não significa o seu desaparecimento. $\mathrm{O}$ que tornou evidente em alguns momentos singulares nas décadas seguintes, o que ultrapassa a análise deste artigo.

Rumo a conclusão. Diante da crise do modelo econômico adotado pela ditadura e o ressurgimento crescente do movimento operário, a autocracia burguesa necessita modificar sua forma política de Estado para tornar permanente o entrelaçamento estrutura da economia brasileira com os países imperialistas e a estrutura política correspondente.

A transição para abertura democrática no Brasil era algo inevitável. O desgaste político da ditadura e os conflitos internos tanto das corporações militares quanto dos setores médios dominantes colocava na ordem do dia a ampliação da participação política como meio de integração formal do Estado brasileiro. Porém, a questão estava encerrada na continuidade da autocracia burguesa e sua institucionalização legitimada pela sociedade brasileira.

A dominação burguesa no Brasil somente se consolida a partir da edificação da estrutura política de segurança abrupta. A ascensão do movimento operário estava articulada com o avanço da crise do modelo econômico, na medida que o primeiro avançava diante das mazelas e sequelas sociais, o segundo entrava numa crise irreversível. Dessa maneira, era evidente a necessidade de criação dos meios políticos para o funcionamento e pacificação dos antagonismos de classes. De um lado, abrir espaço político para absorver 
e manipular as pautas das classes sociais antagônicas. Por outro lado, era necessária a permanência da autocracia burguesa. No primeiro movimento, uma lacuna e abertura política para os conflitos sociais no interior do Estado. No segundo movimento, a continuidade dos mecanismos de contrarrevolução prolongada, seja nos termos do poder político do Estado, seja nos termos econômicos de um novo ciclo de acumulação capitalista. Esta duplicidade do movimento político do Estado brasileiro tem como fatos históricos: a Lei n. 6.683, de 1979 (BRASIL, [2002]) sobre a Anistia que coloca a política do esquecimento como via do retorno à normalidade democrática; a mobilização civil e a traição dos setores médios dominantes que levou a derrota do movimento das Diretas Já! de março 1983 a abril de 1984; por último, o papel decisivo da composição política do centrão na carta final da Constituinte de 1986, que mesclava artigos da Constituição de 1946, legislações do período da ditadura e a ampliação dos diretos sociais dos setores progressistas e da esquerda brasileira.

Em suma, a autocracia burguesa no Brasil se institucionaliza e consolida suas bases políticas por meio da democracia de cooptação, o que significa a continuidade de mecanismos políticos e econômicos de contrarrevolução prolongada, num movimento de fluxo e refluxo, mas, permanente na estrutura política e econômica do país.

\section{Referências}

BRASIL. Lei no 6.683, de 28 de agosto de 1979. Concede anistia e dá outras providências. Brasília, DF: Presidência da República, [2002]. Disponível em: http://www.planalto.gov.br/ccivil_03/LEIS/L6683.htm. Acesso em: 3 ago. 2020.

FERNANDES, F. A revolução burguesa no Brasil: ensaio de interpretação sociológica. 2. ed. Rio de Janeiro: Zahar, 1976.

FERNANDES, F. Capitalismo dependente e classes sociais na América Latina. Rio de Janeiro: Global, 1975.

FERNANDES, F. Circuito fechado: quatro ensaios sobre o "poder institucional”. São Paulo: Globo, 2010.

FERNANDES, F. Poder e contrapoder na América Latina. 2. ed. São Paulo: Expressão Popular, 2015.

HOBSBAWM, E. Ecos da marselhesa: dois séculos revêem a Revolução Francesa. São Paulo: Companhia das Letras, 1996.

MARINI, R. M. Subdesenvolvimento e revolução. 4. ed. Florianópolis: Editora Insular, 2013

MARX, K. Grundrisse: manuscritos econômicos de 185-1858. São Paulo: Boitempo / UFRJ, 2011

PAULO NETTO, J. Pequena história da ditadura brasileira (1964-1985). São Paulo: Cortez, 2014.

PRADO JÚNIOR, C. A revolução brasileira. 5. ed. São Paulo: Brasiliense, 1977.

PRADO JÚNIOR, C. Evolução política no Brasil e outros estudos. São Paulo: Companhia das Letras, 2012.

\section{Notas}

1 A luta pela independência do Haiti de 1804 foi um dos fatos históricos que aterrorizaram as elites senhoriais da América Latina.

2 De acordo com José Paulo Netto (2014, p. 25), a constituição de 1946, proibia o voto dos analfabetos que correspondiam a $40 \%$ da população, em que 12,5 milhões de brasileiros eram eleitores de um total de 70 milhões. Além disso, a configuração socioeconômica da população era predominantemente rural $(53,7 \%)$.

\section{Diogo Prado Evangelista}

diogoprado32@gmail.com

Doutorado em Serviço Social pela Universidade Federal do Rio de Janeiro (UFRJ)

Docente no curso de graduação em Serviço Social da Universidade Federal dos Vales do Jequitinhonha e Mucuri (UFVJM)

\section{UFVJM}

Rua do Cruzeiro, n. 01 - Jardim São Paulo

Teófilo Otoni - Minas Gerais - Brasil

CEP: 39803-371 


\section{Agradecimentos}

Gostaria de agradecer as contribuições no debate, reflexão e pesquisa do Grupo de Estudo do Pensamento LatinoAmericano (GEPLA).

Agência financiadora

Não se aplica.

Contribuições das autoras

Não se aplica.

\section{Aprovação por Comitê de Ética}

Não se aplica.

Consentimento para publicação

Consentimento do autor.

Conflito de interesses

Não há conflito de interesses. 